Proceedings

\title{
Using the MultiRAEPro Gas Detector to Monitor Odour Emissions from Biogas Plants Processing Municipal Waste ${ }^{\dagger}$
}

\author{
Marta Wiśniewska \\ Faculty of Building Services, Hydro and Environmental Engineering, Warsaw University of Technology, \\ Nowowiejska 20 Street, 00-653 Warsaw, Poland; marta.wisniewska.89@wp.pl; Tel.: +48-784-942-572 \\ + Presented at Innovations-Sustainability-Modernity-Openness Conference (ISMO'19), Bialystok, Poland, \\ 22-23 May 2019.
}

Published: 16 July 2019

\begin{abstract}
The aim of this study was to analyse the work of the MultiRAEPro gas detector in terms of its application in monitoring odour emissions from biogas plants processing municipal waste constituting part of a mechanical-biological waste treatment plant. The obtained results provided the basis for formulating conclusions concerning the use of a gas detector in monitoring odour emissions from biogas plants processing municipal waste. The study results can be applied in practice in biogas plants processing municipal waste as well as in other municipal facilities.
\end{abstract}

Keywords: mechanical-biological treatment; odour nuisance; odour concentration

\section{Introduction}

In addition to the unquestionable benefits related to the production of electricity and heat, biogas plants processing municipal waste also have a negative effect in the form of odour emissions. Odour emissions constitute a problem when they influence public health as a result of the dispersion of diseases and/or through being a source of nuisance to nearby inhabitants [1,2]. Complaints of residents in the vicinity of waste management plants often motivate research on odour emissions for the purpose of limiting the impact of the emissions. An important element of this type of research is the identification of the type of odorants causing the odours. A characteristic property of odorants is their negative effect on the human sense of smell-odour [3,4]. This paper presents a tool for the measurement of odour emissions expressed in odorant concentrations. Using the example of two biogas plants located in Wólka Rokicka and Stalowa Wola in Poland, the results of measurement tests carried out using a gas detector are presented. The conducted research allowed us to confirm the suitability of the analysed device for monitoring odorant emissions in waste processing plants, which also include biogas plants processing municipal waste.

\section{Materials and Methods}

The research involved the application of a multi-gas detector MultiRAE Pro (RAE Systems, Inc.; San Jose [California, USA]). The device was equipped with four sensors for the detection of gas concentrations (ammonia, hydrogen sulphide, methyl mercaptan, and volatile compounds). Using the detector, the concentrations of odorants in the studied plants were determined. The detector cooperates with ProRAE Studio software (RAE System), permitting results to be recorded every minute.

In order to analyse the operation of the device, two biogas plants processing municipal waste were tested. The plants are located in Wólka Rokicka and Stalowa Wola in Poland. The tests were carried out on 19 February 2019. 
The research also covered odour measurements, including determination of odour intensity by means of sensory assessment on a six-level scale $(0-5)$, where " 0 " means "no odour", and " 5 " means "very strong odour", and measurement of the multitude of dilution of contaminated air with treated air (D/T - dilution to threshold) by means of a dynamic olfactometer Nasal Ranger (St. Croix Sensory, Inc.; Stillwater [Minnesota, USA]). Based on the known parameter $\mathrm{D} / \mathrm{T}$, odour concentrations were calculated at each of the study receptors [4-6].

\section{Results and Discussion}

Research conducted in the plants permitted the identification of sources of odour emissions in the analysed plants, which included: the hall of waste storage, the hall of the preliminary processing of waste, the hall of the preparation of substrate for fermentation, the hall of oxygen stabilization, the post-fermentation dewatering hall (in Stalowa Wola), the pile field, the surface of the open biofilter, and the retention reservoir of technological sewage. From the moment of commencement to the moment of completion of the study, the gas detector continuously recorded concentrations of the analysed odorants, allowing for information to be obtained concerning odorant emission at the plants. Figures 1 and 2 present graphs showing fluctuations in the concentrations of the following chemical compounds: ammonia, hydrogen sulphate, volatile organic compounds, and methyl mercaptan. The values in the diagrams indicate the results of measurements recorded by the gas detector every minute throughout the duration of the measurement series at a given plant. By monitoring the time during the research, the concentrations of odorants emitted by a specific emission source can be read from the graphs. Odour intensity and odour concentration were also determined for each odour source.

Measurement research with the application of the analysed devices can facilitate measures aimed at minimising odour emission and finding the relation between odour emission and the type of processed waste, technological processes, and technological regime. The obtained results of measurements at the selected sources of odour emissions are related to the intensity and concentration of odour determined at the same points.

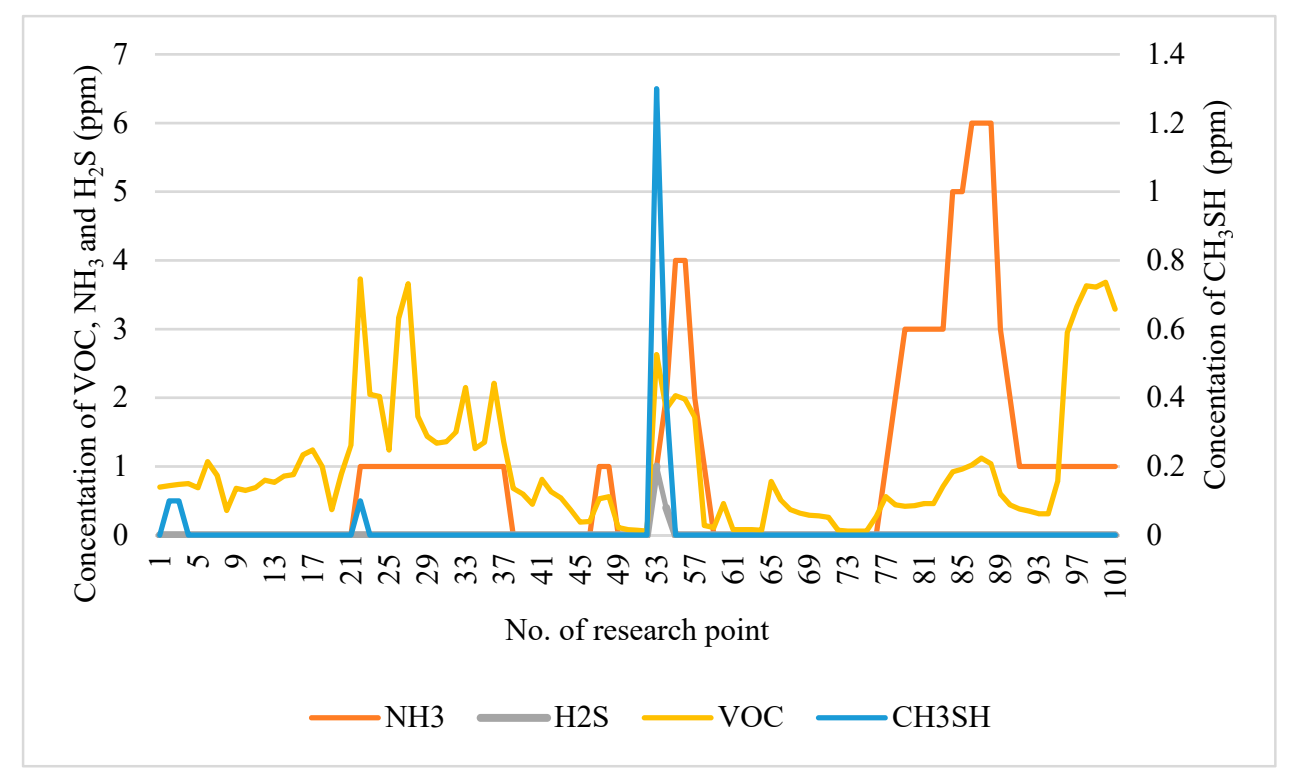

Figure 1. Diagram showing odorant measurement results in the biogas plant in Wólka Rokicka (own elaboration based on ProRae Studio software). 


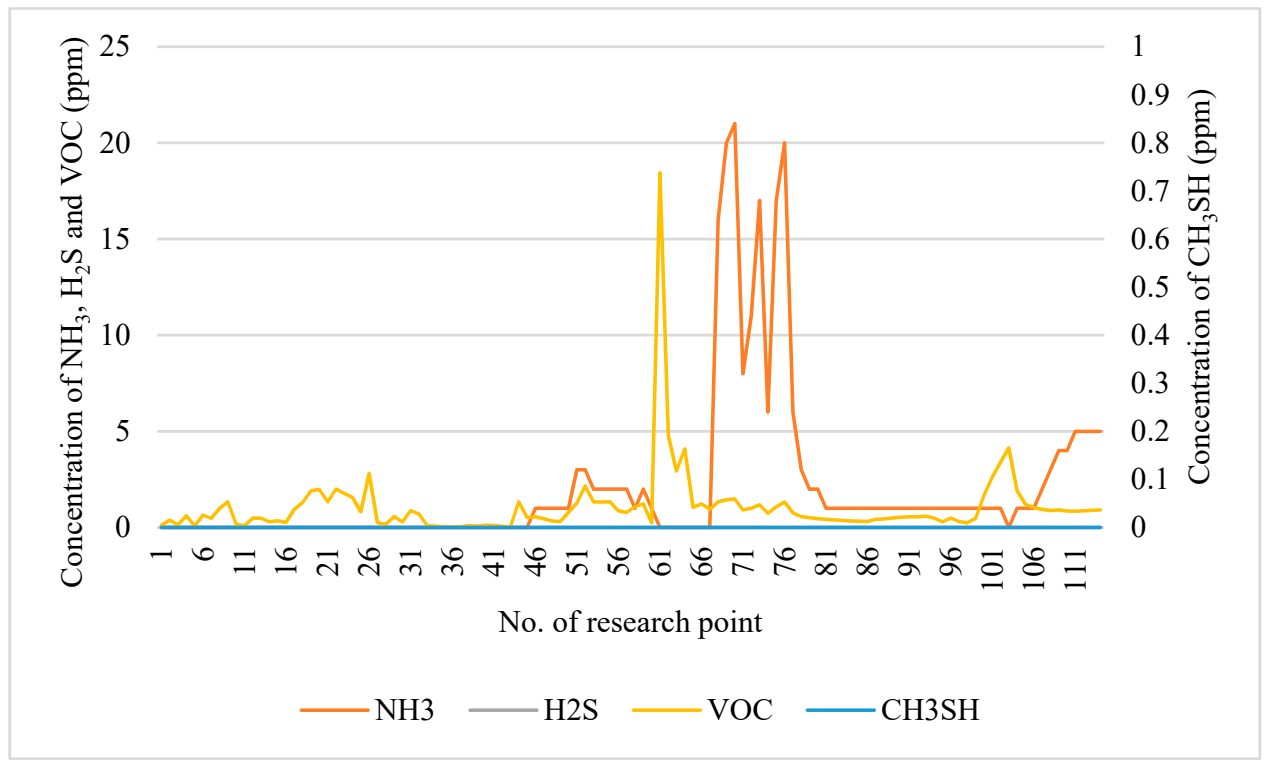

Figure 2. Diagram showing odorant measurement results in the biogas plant in Stalowa Wola (own elaboration based on ProRae Studio software).

\section{Conclusions}

The obtained results provided the basis for the formulation of conclusions concerning the use of a gas detector to monitor odour emissions from biogas plants processing municipal waste. The chemical compounds for which the concentrations are indicated by the equipment (i.e.; ammonia, hydrogen sulphide, volatile organic compounds) are included in the Best Available Techniques (BAT) conclusions on waste treatment [7] as chemical compounds that should be monitored.

By combining different measurement methods, it is possible to characterise the odour emission sources on site, which is important for minimising odour nuisance, as well as for ensuring the comfort and safety of employees working in the plants. The study results can be applied in practice in biogas plants processing municipal waste as well as in other municipal facilities.

Author Contributions: M.W. conceived, designed and performed the experiments, analysed the data, contributed materials/analysis tools, and wrote the paper.

Acknowledgements: The portable gas detector was financed by the Dean's grant No. 504/03693/1110/42.000100 as part of the following study:"Identification and preliminary characteristics of odour sources in biogas plants processing municipal waste".

Conflicts of Interest: The author declares no conflict of interest.

\section{References}

1. Orzi V.; Scaglia, B.; Lonati, S.; Riva, C.; Boccasile, G.; Alborali, G.L.; Adani, F. The role of biological processes in reducing both odour impact and pathogen content during mesophilic anaerobic digestion. Sci. Total Environ. 2015, 526, 116-126, doi:10.1016/j.scitotenv.2015.04.038.

2. Orzi V.; Riva C.; Scaglia B.; D'Imporzano G.; Tambone F.; Adani F. Anaerobic digestion coupled with digestate injection reduced odour emissions from soil during manure distribution. Sci. Total Environ. 2018, 621, 168-176, doi:10.1016/j.scitotenv.2017.11.249.

3. Cheng Z.; Sun Z.; Zhu S.; Lou Z.; Zhu N.; Feng L. The identification and health risk assessment of odor emissions from waste landfilling and composting. Sci. Total Environ. 2019, 649, 168-176, doi:10.1016/j.scitotenv.2018.08.230.

4. Kulig, A. Metody pomiarowo-obliczeniowe w ocenach oddziaływania na środowisko obiektów gospodarki komunalnej [Measurement-calculation methods in environmental impact assessments of waste management objects], Warszawa, 2004. 
5. Szulczyński B. Szulczyński B.; Dymerski T.; Gębicki J.; Namieśnik J. Instrumental measurement of odour nuisance in city agglomeration using electronic nose. E3S Web Conf. 2018, 28, doi:10.1051/e3sconf/20182801012.

6. Wiśniewska M.; Kulig A.; Lelicińska-Serafin K. Identification and preliminary characteristics of odour sources in biogas plants processing municipal waste. SHS Web Conf. 2018, 57, doi:10.1051/shsconf/20185702016.

7. Decyzja Wykonawcza Komisji (UE) 2018/1147 z dnia 10 sierpnia 2018 r. ustanawiająca konkluzje dot. Najlepszych dostępnych technik (BAT) w odniesieniu do przetwarzania odpadów zgodnie z dyrektywą Parlamentu Europejskiego i Rady 2010/75/UE. [Commission Executive Decision (EU) 2018/1147 of 10 August 2018 establishing best available techniques (BAT) conclusions for waste treatment pursuant to the directive of the European Parliament and the Council 2010/75/EU].

(C) 2019 by the authors. Licensee MDPI, Basel, Switzerland. This article is an open access article distributed under the terms and conditions of the Creative Commons Attribution (CC BY) license (http://creativecommons.org/licenses/by/4.0/). 